\title{
PEMANFAATAN LIMBAH PRODUKSI KAKAO UNTUK PAKAN BENIH IKAN NILA (Oreochromis niloticus)
}

\author{
Vitas Atmadi Prakoso ${ }^{1)}$, Hendy Firmanto ${ }^{2)}$, Kurniawan ${ }^{3)}$ \\ 1)*Balai Penelitian dan Pengembangan Budidaya Air Tawar \\ ${ }^{2)}$ Pusat Penelitian Kopi dan Kakao Indonesia \\ ${ }^{3)}$ Badan Penelitian dan Pengembangan Kelautan dan Perikanan \\ *e-mail : vitas.atmadi@gmail.com
}

\begin{abstract}
Utilization of Waste Production of Cocoa for Tilapia Fish (Oreochromis niloticus) Seed Feed

Problems often arise in fish farming is the cost of artificial feed (pellets) which is expensive. The availability of local feed ingredients are still very limited and reliance on imports causing feed prices to rise. Therefore we need research to find alternative raw materials that can substitute fish meal price is relatively cheaper, widely available, and do not compete with cattle and human needs. Raw materials include cocoa shell waste derived from cocoa plantations. This study aimed to evaluate the use of cocoa shell waste for growing out of tilapia fish (Oreochromis niloticus). The study was conducted at the Center for Research and Development of Freshwater Aquaculture, Bogor. When the study will be conducted over two months. The fish used were tilapia fish 7-8 cm size were maintained on media aquarium measuring $50 \times 40 \times 40 \mathrm{~cm}$. In addition, the feed given that the result of the fortification of rind cocoa powder, cocoa seed shell powder, rice bran, tapioca flour, water and salt. Commercial feed was also used in this study as a comparison. Feed given as much as $3 \%$ of the total biomass of fish in each aquarium. Every two weeks the data collection of body length and weight of fish seeds were measured. The data would be observed that the length and absolute weight, specific growth rate (SGR), increase biomass and fish survival rate. The results of this study indicated that tilapia fish fed the formulation of cocoa waste could not achieve the growth of fish with commercial feed. Further studies on cocoa waste hopely be better to produce fish seeds which same growth with the growth of fish fed by commercial feed.
\end{abstract}

Key words: Feed, waste of cocoa, tilapia, Oreochromis niloticus

\begin{abstract}
ABSTRAK
Permasalahan yang sering muncul pada usaha budidaya ikan yaitu biaya pakan buatan (pellet).yang mahal. Ketersediaan bahan baku pakan lokal masih sangat terbatas dan ketergantungan pada impor menyebabkan harga pakan meningkat. Oleh karena itu diperlukan penelitian untuk mencari alternatif bahan baku yang dapat menjadi substitusi tepung ikan dengan harga yang relatif murah, banyak tersedia, dan tidak bersaing dengan kebutuhan ternak dan manusia. Bahan baku tersebut antara lain limbah kulit kakao yang berasal dari perkebunan kakao. Penelitian ini bertujuan untuk mengevaluasi pemanfaatan limbah kulit kakao untuk pembesaran benih ikan nila (Oreochromis niloticus). Penelitian dilakukan di Balai Penelitian dan Pengembangan Budidaya Air Tawar, Bogor. Waktu penelitian akan dilaksanakan selama 2 bulan. Ikan yang digunakan yaitu benih ikan nila ukuran 7-8 $\mathrm{cm}$ yang dipelihara pada media akuarium berukuran $50 \times 40 \times 40 \mathrm{~cm}$. Selain itu, pakan yang diberikan yaitu hasil fortifikasi dari serbuk kulit buah kakao, serbuk kulit biji kakao, dedak padi, tepung tapioka, air, dan garam. Pakan komersil juga digunakan dalam penelitian ini sebagai pembanding. Pakan diberikan sebanyak 3\% dari total biomassa ikan pada masing-masing akuarium. Tiap 2 minggu dilakukan pengambilan data panjang dan bobot tubuh benih ikan yang diuji. Data yang akan diamati yaitu pertambahan panjang dan bobot mutlak, laju pertumbuhan spesifik (SGR), pertambahan biomass, dan sintasan ikan uji. Hasil penelitian ini menunjukkan bahwa benih ikan nila yang diberi pakan formulasi dari limbah kakao belum dapat mencapai pertumbuhan yang setara dengan pakan komersial. Perlu penelitian lebih lanjut mengenai formulasi pakan limbah kakao yang lebih baik lagi agar mampu menghasilkan pertumbuhan benih ikan yang seimbang dengan pertumbuhan ikan yang diberi pakan komersial.
\end{abstract}

Kata Kunci: Pakan, Limbah kakao, Nila, Oreochromis niloticus

\section{PENDAHULUAN}

Biaya pakan merupakan permasalahan yang sering muncul pada usaha budidaya ikan. Dalam kegiatan budidaya ikan, 50-
$70 \%$ total biaya produksi diperuntukkan bagi pakan. Meningkatnya harga pakan dari tahun ke tahun dapat berpengaruh terhadap keuntungan para pembudidaya ikan karena harga jual ikan air tawar yang relatif murah 
dan stabil (Azwar et al., 2010; Sunarno, et al., 2011). Meningkatnya harga pakan disebabkan karena ketersediaan bahan baku pakan lokal masih sangat terbatas, sebagian besar tergantung pada impor. Bahan baku utama pakan baik komersial maupun buatan adalah tepung ikan yang merupakan sumber protein utama pada formulasi pakan. Kebutuhan tepung ikan di Indonesia sekitar 100.000-120.000 ton per tahun. Sebanyak 75.000-80.000 ton di antaranya dipenuhi dari impor, dan sisanya $25.000-40.000$ ton dipenuhi dari produksi dalam negeri (Giri, 2013).

Pakan memegang peranan penting dalam proses keberhasilan usaha budidaya perikanan. Menurut Weatherley dan Gill (1987), pertumbuhan ikan dipengaruhi oleh beberapa faktor, yaitu makanan, ruang, suhu, dan aktifitas fisik. Kualitas pakan yang baik menentukan kualitas ikan yang dihasilkan (Zonneveld et al., 1991). Pakan mempengaruhi laju pertumbuhan, produksi, kesehatan, kelangsungan hidup, dan reproduksi ikan (Samsudin dan Djajasewaka, 2009). Selain itu, kecepatan pertumbuhan juga merupakan faktor penting dalam budidaya. Pakan harus memenuhi kebutuhan energi ikan (Wooton, 1979). Oleh karena itu, diperlukan pakan dengan kualitas yang baik agar menghasilkan benih ikan yang berkualitas baik.

Dalam rangka melakukan efisiensi penggunaan tepung ikan dan sekaligus mengurangi ketergantungan terhadap tepung ikan maka diperlukan penelitian untuk mencari alternatif bahan baku yang dapat menjadi substitusi tepung ikan dengan harga yang relatif murah, banyak tersedia dan tidak bersaing dengan kebutuhan ternak dan manusia. Salah satu sumberdaya yang memiliki potensi untuk dikembangkan sebagai bahan baku pakan ikan adalah limbah biomassa dari pertanian dan perkebunan, salah satunya yaitu kulit biji kakao sangrai. Kulit biji kakao pasca sangrai (cocoa shell) memiliki kandungan protein 17,6\% (Mahyuddin, 1995). Kulit biji kakao merupakan limbah produksi kakao yang banyak terdapat di perkebunan kakao.

Protein mempunyai peranan penting bagi pertumbuhan ikan sebagai sumber energi. Mudjiman (2004) menyatakan bahwa secara alami energi yang dibutuhkan oleh ikan bersumber dari protein. Protein digunakan untuk pertumbuhan dan pemeliharaan tubuh. Selain protein, faktor lain yang penting adalah lemak. Izquierdo et al. (2001) menyatakan bahwa lemak dan komposisi asam lemak pakan merupakan salah satu faktor yang mendukung keberhasilan tingkat kelangsungan hidup benih.

Untuk membuat pakan dari bahan baku tersebut diperlukan formulasi yang tepat untuk memenuhi semua kebutuhan nutrien dari ikan, seperti protein, asam amino, lemak, asam lemak, energi, vitamin dan mineral. Kebutuhan protein dapat dipenuhi oleh limbah kulit kakao. Kebutuhan serat dan energi dapat dipenuhi oleh limbah dedak padi atau pollard, sedangkan kebutuhan vitamin dan mineral dapat dipenuhi oleh garam dapur atau umbi-umbian (Hardianto dan Suharyono, 2002). Selain itu juga masih diperlukan penambahan bahan lain yang bersifat atraktan atau berfungsi untuk menarik nafsu makan (Adelina et al., 2005). Pembuatan pakan dapat dilakukan melalui proses formulasi dan fortifikasi kemudian dipadatkan dalam bentuk konsentrat menggunakan mesin pelet dengan kapasitas tertentu sehingga dihasilkan bentuk pakan yang stabil dan tidak cepat hancur sehingga tidak mudah kehilangan kandungan gizinya (Adelina et al., 2005).

Kebutuhan nutrien setiap jenis ikan berbeda-beda namun protein perlu mendapatkan perhatian utama karena $65-75 \%$ tubuh ikan terdiri atas protein. Jenis ikan air tawar yang akan dijadikan target percobaan pada penelitian ini adalah ikan nila (Oreochromis niloticus). Tujuan dari peneliti-an ini adalah untuk mengevaluasi peman-faatan limbah kulit kakao untuk pembesaran benih ikan nila (Oreochromis niloticus).

\section{BAHAN DAN METODE}

Penelitian ini dilaksanakan di Laboratorium Basah, Balai Penelitian dan Pengembangan Budidaya Air Tawar, Bogor. Ikan yang digunakan yaitu benih ikan nila ukuran 7 - $8 \mathrm{~cm}$ dengan kepadatan ikan pada masing-masing akuarium sebanyak 20 ekor. 
Ikan dipelihara di akuarium dalam sistem resirkulasi berjumlah 9 buah. Ukuran akuarium yang digunakan yaitu 50 x 40 x 40 $\mathrm{cm}$. Bobot benih diukur menggunakan timbangan digital, sedangkan panjang diukur dengan menggunakan penggaris 30 $\mathrm{cm}$ dengan ketelitian $1 \mathrm{~mm}$. Terdapat 2 perlakuan, yaitu perlakuan pemberian pakan formulasi dari limbah kakao dan pakan komersial. Pakan diberikan kepada benih ikan nila sebanyak 2 kali sehari. Sampling pengukuran pertumbuhan bobot dan panjang dilakukan setiap 2 minggu sekali. Sintasan dihitung pada akhir perlakuan pemeliharaan untuk setiap perlakuan.

Pertumbuhan mutlak panjang, bobot, dan biomassa merupakan selisih dari panjang/bobot/biomassa akhir dan panjang/bobot/biomassa awal pemeliharaan. Pertumbuhan mutlak dihitung dengan rumus :

$$
\mathrm{PM}=\mathrm{W}_{\mathrm{t}}-\mathrm{W}_{0}
$$

dimana :

$$
\begin{aligned}
\mathrm{PM} & =\text { pertumbuhan } \\
\mathrm{W}_{\mathrm{t}} & =\text { rata-rata pertumbuhan mutlak } \\
& \text { pada saat akhir }(\mathrm{g}) \\
\mathrm{W}_{0} & \begin{array}{l}
\text { = rata-rata pertumbuhan mutlak } \\
\text { pada saat awal }(\mathrm{g})
\end{array}
\end{aligned}
$$

Laju pertumbuhan harian diukur menggunakan rumus Weatherley \& Gill (1987) :

$$
L P H=\frac{\ln W t-\ln W o}{t} \times 100 \%
$$

dimana :

LPH : laju pertumbuhan harian (\%)

Wt : bobot rata-rata ikan pada saat akhir (g)

W0 : bobot rata-rata ikan pada saat awal (g)

$\mathrm{t}$ : lama perlakuan (hari)

Sintasan adalah persentase jumlah benih yang hidup pada akhir pengamatan dibandingkan jumlah larva pada awal pemeliharaan. Sintasan dihitung berdasarkan rumus :

$$
\text { Sintasan }(\%)=\frac{N t}{N o} \times 100 \%
$$

dimana :

$\mathrm{Nt}$ : jumlah benih pada saat akhir pemeliharaan (ekor)

N0 : jumlah benih pada saat awal pemeliharaan (ekor)

Data yang diperoleh dianalisa menggunakan software SPSS untuk menguji tingkat perbedaan yang ada.

\section{HASIL DAN PEMBAHASAN}

Benih ikan nila memiliki pertumbuhan panjang yang lebih rendah pada perlakuan pemberian pakan formulasi limbah perkebunan kakao $(\mathrm{P}<0,05)$ (Tabel 1). Sama halnya dengan pertumbuhan panjang, pertumbuhan bobot ikan nila pada perlakuan pemberian pakan formulasi juga lebih rendah dibandingkan perlakuan pemberian pakan komersial.

Dalam usaha budidaya ikan, ketersediaan pakan dalam jumlah yang cukup, tepat waktu, dan bernilai gizi baik merupakan salah satu faktor penting guna memaksimalkan pro-duktivitas perikanan (Sahwan, 2002). Dari hasil penelitian menunjukkan bahwa ikan yang diberi pakan formulasi dari limbah kakao mempunyai pertambahan panjang yang tidak lebih baik dan secara signifikan lebih rendah dibanding perlakuan benih ikan yang diberi pakan komersial. Lebih rendahnya pertumbuhan benih ikan nila yang diberi pakan formulasi limbah kakao ini dimung-kinkan karena benih ikan nila yang diberi pakan formulasi dari limbah perkebunan kakao belum mendapatkan nutrisi yang cukup untuk pertumbuhan. Hal ini diperkuat dengan hasil analisa proksimat yang menunjukkan bahwa pakan formulasi dari limbah per-kebunan kakao memiliki kandungan protein sebesar $13,11 \%$, sedangkan pakan komersial kandungan proteinnya sebesar $31 \%$. Benih ikan nila memerlukan pakan dengan kan-dungan nutrisi yang optimal untuk tumbuh. Menurut Mudjiman (2004), kadar protein yang diperlukan oleh ikan air tawar yaitu di kisaran $20-60 \%$, dengan nilai optimum 30$36 \%$. Selain protein, lemak juga harus ada dalam pakan sebagai sumber energi utama bagi ikan. 
Tabel 1. Pertumbuhan Panjang dan Bobot Mutlak Benih Ikan Nila

\begin{tabular}{ccc}
\hline $\begin{array}{c}\text { Perlakuan } \\
\text { Treatment }\end{array}$ & $\begin{array}{c}\text { Pertumbuhan panjang mutlak } \\
\text { Total length growth }(\mathrm{cm})\end{array}$ & $\begin{array}{c}\text { Pertumbuhan bobot mutlak } \\
\text { Total weight growth }(\mathrm{g})\end{array}$ \\
\hline Pakan komersial & $2,52 \pm 0,19^{\mathrm{a}}$ & $15,30 \pm 2,72^{\mathrm{a}}$ \\
Pakan formulasi & $0,51 \pm 0,21^{\mathrm{b}}$ & $1,93 \pm 0,69^{\mathrm{b}}$ \\
\hline
\end{tabular}

Tabel 2. Pertumbuhan Panjang dan Bobot Mutlak Benih Ikan Nila

\begin{tabular}{lccc}
\hline \multicolumn{1}{c}{$\begin{array}{c}\text { Perlakuan } \\
\text { Treatment }\end{array}$} & $\begin{array}{c}\text { Pertumbuhan } \\
\text { biomassa } \\
\text { Biomass gain }(\mathrm{g})\end{array}$ & $\begin{array}{c}\text { Sintasan } \\
\text { Survival rate }(\%)\end{array}$ & $\begin{array}{c}\text { Laju Pertumbuhan Harian } \\
\text { Specific Growth Rate }(\%)\end{array}$ \\
\hline Pakan & $272,30 \pm 36,91^{\mathrm{a}}$ & $88,67 \pm 0,58^{\mathrm{a}}$ & $1,74 \pm 0,20^{\mathrm{a}}$ \\
komersial & $23,31 \pm 9,80^{\mathrm{b}}$ & $88,67 \pm 0,58^{\mathrm{a}}$ & $0,33 \pm 0,11^{\mathrm{b}}$ \\
Pakan formulasi & & & \\
\hline
\end{tabular}

Sama halnya dengan pertumbuhan panjang dan bobot, benih ikan nila pada perlakuan pakan formulasi limbah kakao memiliki pertumbuhan biomassa lebih rendah dibandingkan pakan komersial $(\mathrm{P}<0,05)$ (Tabel 2). Kedua perlakuan tersebut memiliki persentase sintasan yang sama, yaitu $88,67 \pm 0,58 \%$. Sedangkan untuk laju pertumbuhan harian ikan nila pada perlakuan pemberian pakan formulasi limbah kakao sebesar $0,33 \pm 0,11 \%$. Nilai tersebut lebih rendah dan ber-beda nyata dengan perlakuan pakan komersial $(1,74 \pm$ $0,20 \%)$.

Laju pertumbuhan harian tertinggi diperoleh pada perlakuan pakan komersial dan berbeda nyata $(\mathrm{P}<0,05)$. Laju pertumbuhan tersebut termasuk rendah, hal tersebut diduga karena kondisi akuarium yang kurang men-dukung untuk proses pertumbuhan benih ikan. Apabila pakan yang diberikan memiliki kandungan nutrisi yang baik, maka dapat mempercepat laju pertumbuhan karena zat tersebut akan dimanfaatkan untuk meng-hasilkan energi dalam proses penggantian sel-sel tubuh yang rusak. Zat-zat nutrisi yang dibutuhkan tersebut yaitu protein, lemak, karbohidrat, vitamin, dan mineral (Handajani dan Widodo, 2010). Faktor lain yang juga berpengaruh terhadap pertumbuhan ikan adalah transformasi makanan menjadi jaringan tubuh ikan seperti jumlah pakan yang dikonsumsi, kecernaan makanan, laju pencernaan, frekuen-si pemberian pakan, penyerapan zat makanan, serta efisiensi dan konversi pakan (Dharma dan Suhenda, 1986).

Meningkatnya harga pakan merupakan salah satu hambatan dalam usaha budidaya ikan nila, ditambah lagi dengan harga jual ikan nila yang rendah dan tidak mengikuti harga pakan. Beberapa upaya pembudidaya untuk menekan biaya pakan telah dilakukan antara lain pembuatan pakan dengan memanfaatkan bahan baku lokal (Sunarno et al. 2012; Kontara et al., 2013; Samsudin et al., 2013). Dari hasil penelitian tersebut, pakan uji memiliki nilai tidak berbeda nyata dengan pakan komersial untuk pembesaran ikan. Hal ini menunjukkan bahwa penggunaan pakan berbasis bahan baku lokal memiliki kualitas yang baik dengan harga yang relatif lebih murah sehingga dapat digunakan oleh pembudidaya. Berdasarkan informasi tersebut, pakan formulasi dari limbah perkebunan kakao dapat menjadi alternatif bagi pembudidaya untuk menggantikan pakan komersial meskipun dari penelitian ini belum diperoleh hasil yang optimal dari pemberian pakan hasil limbah perkebunan kakao dibandingkan dengan pakan komersial. Oleh karena itu, diperlukan penelitian lebih lanjut mengenai formulasi pakan yang tepat dari limbah perkebunan kakao agar benih ikan nila dapat tumbuh seperti layaknya ikan tersebut diberi pakan komersial. 


\section{KESIMPULAN}

Benih ikan nila yang diberi pakan formulasi dari limbah kakao belum dapat mencapai pertumbuhan yang setara dengan pakan komersial. Hasil ini menunjukkan bahwa perlu penelitian lebih lanjut mengenai formulasi pakan limbah kakao yang lebih baik lagi agar mampu menghasilkan pertumbuhan benih ikan yang seimbang dengan pertum-buhan ikan yang diberi pakan komersial.

\section{DAFTAR PUSTAKA}

Adelina, Boer, dan Suharman. 2004. Analisis Formulasi Pakan. Unri Press. Pekanbaru.

Azwar, Z.I. dan R. Rostika. 2010. Ketersediaan dan peningkatan kualitas bahan baku pakan ikan dan udang. Semiloka nutrisi pakan ikan dan udang. Badan Litbang Kelautan dan Perikanan, Kementerian Kelautan dan Perikanan, bekerjasama dengan Ikatan Sarjana Perikanan Indonesia. Jakarta.

Dharma, L. dan N. Suhenda. 1986. Pengaruh pemberian pakan dengan tangan dan alat self feeder terhadap pertumbuhan dan produksi ikan mas di kolam air deras. Bulletin Penelitian Perikanan Darat, 5(1): 79-84.

Giri, I.N.A. 2013. Dukungan penelitian pakan terhadap pengembangan budidaya ikan kerapu. Buku Naskah Orasi Profesor Riset. Badan Penelitian dan Pengembangan Kelautand an perikanan. Jakarta

Handajani dan Widodo. 2010. Nutrisi Ikan. UMM Press. Malang.

Hardianto R. dan Suharyono. 2002. Kajian Pemanfaatan Limbah Pertanian dan Limbah Agroindustri Bahan Baku Pakan Ternak di Kabupaten Tulungagung. Laporan Hasil Studi
Kerjasama BPTP Jawa Timur dengan

Bappeda Kabupaten Tulungagung.

Izquierdo, M.S., H Fernandez, Palacios dan A. J. Tacon. 2001. Effect of Broodstock Nutrition on Reproductive Performance of Fish. Aquaculture 197: 25-42.

Kontara EK, R Samsudin dan MTD Sunarno. 2013. Pengembangan Budidaya Ikan Nila (Oreochromis niloticus) di Kolam Tanah dengan Aplikasi Pakan Berbasis Bahan Baku Lokal. Prosiding Forum Inovasi Teknologi Akuakultur 2013, Nusa Tenggara Barat, 11-13 Juni 2013.

Haryanti, Rahmansyah, IN Radiarta, AH Kristanto, Imron, K Sugama, B Pantjara, ZI Azwar (Penyunting), 501-506. Pusat Litbang Perikanan Budidaya.

Mahyuddin P. 1995. The Nutritive value of cocoa shell in ruminants. Bulletin of Animal Science (Special Edition).

Mudjiman, A. 2004. Makanan ikan. Penebar Swadaya. Jakarta. 182p.

Sahwan, F. M. 2002. Pakan Ikan dan Udang. Penebar Swadaya, Jakarta.

Samsudin R., dan H. Djajasewaka, 2009. Percepatan Waktu Rematurasi Gonad Ikan Nilem Dengan Perbaikan Kualitas Pakan Induk. Laporan Seminar Hasil Riset T.A. 2009. Balai Riset Perikanan Budidaya Air Tawar, Bogor.

Samsudin R, M.T.D. Sunarno dan M. Sulhi. 2013. Inovasi pakan efisien dan ekonomis berbasis bahan baku lokal untuk pembesaran ikan nila (Oreochromis niloticus). Prosiding Hasil Penelitian Terbaik Tahun 2013, Jakarta, 12-13 November 2013. A Hanggono, TD Ferindera, H Gumilar, D Kurniawan (Penyunting), 208-216. Badan Litbang Kelautan dan Perikanan. 
Sunarno, MTD., A. Widiyati dan LE. Hadie. 2011. Penyediaan Pakan bagi budidaya ikan lele: Kasus pengembangan di Prov Jawa Barat dan DI Yogyakarta, p: 83-98. A. Sudradjat, MF. Sukadi dan IW. Rusastra (Eds). Analisis Kebijakan Pembangunan Perikanan Budidaya 2011. Swakarya, Jakarta.

Sunarno MTD, M Sulhi, R Samsudin, T Kurnasih, M Wilakstanti, Mulyasari dan LH Suryaningrum. 2012. Formulasi pakan ikan berbasis bahan baku hijauan. Laporan Kegiatan Seminar Hasil Riset 2012, Bogor, Desember 2012. Nuryadi dkk.
(Penyunting). Balai Litbang Budidaya Air Tawar.

Weatherley, A.H and H.S. Gill. 1987. The biology of fish growth. Academic Press, Toronto, Canada, p.443.

Wooton, R. J. 1979. Energy Cost Production and Environmental Determinent of Fecundity on Teleost Fish. In : P.J. Miller (Ed.). Fish Phenology Anabolic Adaptive in Teleost. 133-159. Academy Press inc. London.

Zonneveld, N., E. A. Huisman, J. H. Boon. 1991. Prinsip-prinsip Budidaya Ikan. PT. Gramedia Pustaka Utama. 318p 